Key Words:

Electrolysis

Hydrogen

Hybrid Sulfur

Retention: Permanent

\title{
Fiscal Year 2006 Report on Electrolyzer Component Development for the Hybrid Sulfur Project
}

\author{
H. R. Colon-Mercado \\ D. T. Hobbs \\ D. B. Coleman \\ A. A. Ekechukwu
}

\section{AUGUST 2006}

Savannah River National Laboratory

Washington Savannah River Company

Savannah River Site

Aiken, SC 29808 


\section{DISCLAIMER}

This report was prepared as an account of work sponsored by an agency of the United States Government. Neither the United States Government nor any agency thereof, nor any of their employees, nor any of their contractors, subcontractors or their employees, makes any warranty, express or implied, or assumes any legal liability or responsibility for the accuracy, completeness, or any third party's use or the results of such use of any information, apparatus, product, or process disclosed, or represents that its use would not infringe privately owned rights. Reference herein to any specific commercial product, process, or service by trade name, trademark, manufacturer, or otherwise, does not necessarily constitute or imply its endorsement, recommendation, or favoring by the United States Government or any agency thereof or its contractors or subcontractors. The views and opinions of authors expressed herein do not necessarily state or reflect those of the United States Government or any agency thereof.

\section{Printed in the United States of America}


Key Words:

Electrolysis

Hydrogen

Hybrid Sulfur

Retention: Permanent

\title{
Fiscal Year 2006 Report on Electrolyzer Component Development for the Hybrid Sulfur Project
}

\author{
H. R. Colon-Mercado \\ D. T. Hobbs \\ D. B. Coleman \\ A. A. Ekechukwu
}

AUGUST 2006

Savannah River National Laboratory

Washington Savannah River Company

Savannah River Site

Aiken, SC 29808 


\section{REVIEWS AND APPROVALS}

H. R. Colon-Mercado, Co-author, SCUREF

Date

D. B. Coleman, Co-author, SCUREF

Date

D. T. Hobbs, Co-author, Process Chemistry and Science

Date

A. A. Ekechukwu, Co-author, Analytical Development

Date

T. J. Steeper, Technical Reviewer, Engineered Equipment \& Systems Dept.

Date

W. A. Summers, Manager, Energy Security

Date

- ii - 


\section{TABLE OF CONTENTS}

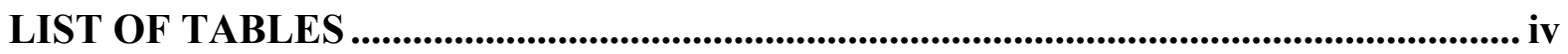

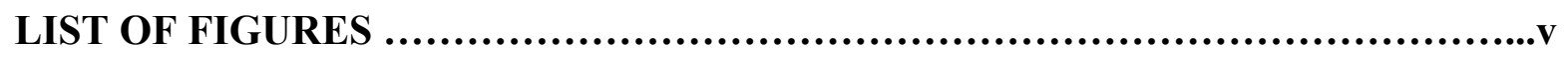

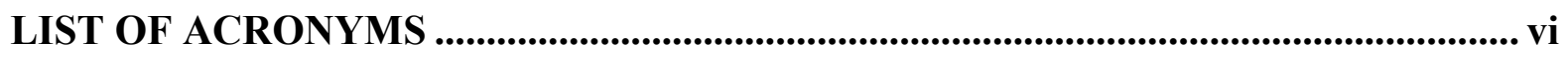

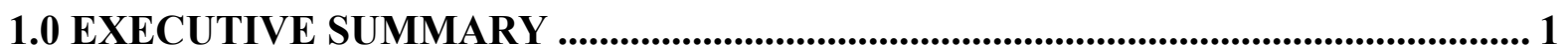

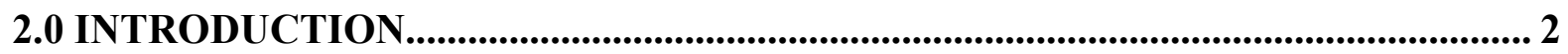

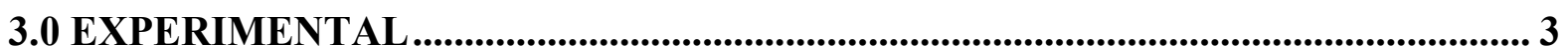

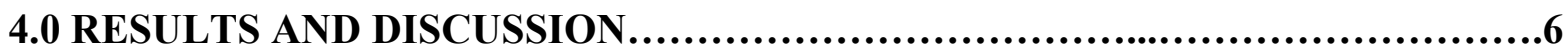

5.0 CONCLUSION AND RECOMMENDATIONS............................................................... 17

6.0 REFERENCES................................................................................................................ 19 


\section{LIST OF TABLES}

Table 1. Evaluated Membranes .3

Table 2. Comparison of diffusion coefficient and ionic resistance in evaluated

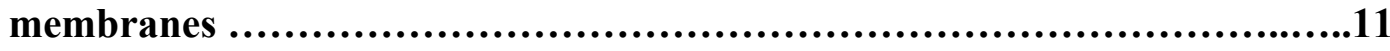




\section{LIST OF FIGURES}

Figure 1. Simplified schematic of the membrane characterization cell...................4

Figure 2. Simplified schematic of the catalyst characterization cell......................5

Figure 3. $\mathrm{SO}_{2}$ transport through PFSA membranes immersed in 30 wt.\% $\mathrm{H}_{2} \mathrm{SO}_{4}$ saturated with $\mathrm{SO}_{2}$ at room temperature. Working electrode set at $1040 \mathrm{mV}$ vs. SHE ...........................................................................7

Figure 4: $\mathrm{SO}_{2}$ transport through non-PFSA membranes immersed in $30 \mathrm{wt} . \% \mathrm{H}_{2} \mathrm{SO}_{4}$ saturated with $\mathrm{SO}_{2}$ at room temperature. Working electrode set at $1040 \mathrm{mV}$ vs. SHE......................................................................8

Figure 5: Steady state $\mathrm{SO}_{2}$ flux through the tested membranes immersed in 30 wt.\% $\mathrm{H}_{2} \mathrm{SO}_{4}$ saturated with $\mathrm{SO}_{2}$ at room temperature. Working electrode set at $1040 \mathrm{mV}$ vs. SHE.

Figure 6. Impedance response of a typical proton conducting membrane in $30 \mathrm{wt} . \%$

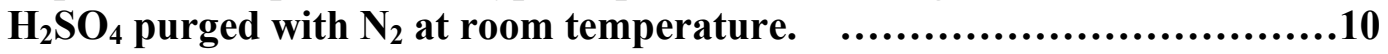

Figure 7. Proton conductivity in 30 wt.\% $\mathrm{H}_{2} \mathrm{SO}_{4}$ purged with $\mathrm{N}_{2}$ at room temperature...............................................................11

Figure 8. Cyclic voltammograms after consecutive cycling for $\mathrm{Pt} / \mathrm{C}$ (left) and $\mathrm{Pd} / \mathrm{C}$ (right) in 30 wt.\% (a), 50 wt.\% (b), and 70 wt.\% (c) $\mathrm{H}_{2} \mathrm{SO}_{4}$ purged with $\mathrm{N}_{2}$ at room temperature.

Figure 9. Hydrogen desorption peak height after consecutive cycling (see Figure 8) for $\mathrm{Pt} / \mathrm{C}$ (left) and $\mathrm{Pd} / \mathrm{C}$ (right) in sulfuric acid purged with $\mathrm{N}_{2}$ at room temperature....................................................................14

Figure 10. Tafel plots for $\mathrm{SO}_{2}$ oxidation on $\mathrm{Pt} / \mathrm{C}$ (left) and $\mathrm{Pd} / \mathrm{C}$ (right) in sulfuric acid saturated with $\mathrm{SO}_{2}$ at room temperature.

Figure 11. Simplified schematic of the SDE and the processes taking place (a) and scanning electron microscopy of the MEA (b)................................16 


\section{LIST OF ACRONYMS}

$\begin{array}{ll}\text { BAS } & \text { Bioanalytical Systems } \\ \text { CCE } & \text { Catalyst Coated Electrode } \\ \text { CCM } & \text { Catalyst Coated Membrane } \\ \text { CV } & \text { Cyclic Voltammogram } \\ \text { DI-water } & \text { Deionized water } \\ \text { EIS } & \text { Electrochemical Impedance Spectroscopy } \\ \text { EW } & \text { Equivalent Weight } \\ \text { HyS } & \text { Hybrid Sulfur } \\ \text { LSV } & \text { Linear Sweep Voltammogram } \\ \text { MEA } & \text { Membrane Electrode Assembly } \\ \text { OCP } & \text { Open Circuit Potential } \\ \text { OPM } & \text { Oxford Performance Materials } \\ \text { PBI } & \text { Poly-Benzimidazole } \\ \text { PEM } & \text { Proton Exchange Membrane and Polymer Electrolyte Membrane } \\ \text { PEMFC } & \text { Polymer Electrolyte Membrane Fuel Cell } \\ \text { PFSA } & \text { Perfluorinated Sulfonic Acid } \\ \text { RT } & \text { Room Temperature, 25 }{ }^{\circ} \text { C } \\ \text { SCUREF } & \text { South Carolina Universities Research and Education Foundation } \\ \text { SDE } & \text { Sulfur Dioxide-depolarized Electrolyzer } \\ \text { SEM } & \text { Scanning Electron Microscopy } \\ \text { SHE } & \text { Standard Hydrogen Electrode } \\ \text { SPEK } & \text { Sulfonated Poly-Etherketone } \\ \text { SPEKK } & \text { Sulfonated Poly-Etherketone-ketone } \\ \text { SRNL } & \text { Savannah River National Laboratory } \\ \text { SRS } & \text { Savannah River Site }\end{array}$




\subsection{EXECUTIVE SUMMARY}

Thermochemical processes are being developed to provide global-scale quantities of hydrogen. A variant on sulfur-based thermochemical cycles is the Hybrid Sulfur (HyS) Process which uses a sulfur dioxide depolarized electrolyzer (SDE) to produce the hydrogen. In FY05, testing at the Savannah River National Laboratory (SRNL) explored a low temperature fuel cell design concept for the SDE. The advantages of this design concept include high electrochemical efficiency and small volumetric footprint that is crucial for successful implementation on a commercial scale.

A key component of the SDE is the ion conductive membrane through which protons produced at anode migrate to the cathode and react to produce hydrogen. An ideal membrane for the SDE should have both low ionic resistivity and low sulfur dioxide transport. These features allow the electrolyzer to perform at high currents with low potentials, along with preventing contamination of both the hydrogen output and poisoning of the catalysts involved. Another key component is the electrocatalyst material used for the anode and cathode. Good electrocatalysts should be chemically stable and low overpotential for the desired electrochemical reactions.

This report summarizes results from activities to evaluate different membrane and electrocatalyst materials for the SDE. Several different types of commercially-available membranes were analyzed for ionic resistance and sulfur dioxide transport including perfluorinated sulfonic acid, sulfonated poly-etherketone-ketone, and poly-benzimidazole membranes. Of these membrane types, the poly-benzimidazole (PBI) membrane, Celtec-L, exhibited the best combination of characteristics for use in an SDE.

Testing examined the activity and stability of platinum and palladium as electrocatalyst for the SDE in sulfuric acid solutions. Cyclic and linear sweep voltammetry revealed that platinum provided better catalytic activity with much lower potentials and higher currents than palladium. Testing also showed that the catalyst activity is strongly influenced by concentration of the sulfuric acid.

Various cell configurations were examined with respect to the deposition of electrocatalyst and use of conductive carbon materials such as carbon cloth and carbon paper. Findings from these evaluations and the results of the membrane and electrocatalyst testing, we prepared three different membrane electrode assemblies (MEA) for electrolyzer testing. The first MEA consisted of a Nafion ${ }^{\circledR}$ membrane with platinum electrocatalyst deposited on carbon cloths, which were heat pressed onto the membrane, an assembly identical to those used in proton exchange membrane fuel cells. The second MEA also used a Nafion membrane with the electrocatalysts deposited directly onto the membrane. The third MEA proved similar to the second but utilized a PBI membrane in place of the Nafion ${ }^{\circledR}$ membrane.

Tailor of the membrane and catalysts properties for the SDE system was concluded as a required step for the technology to move forward. It was also recommended the evaluation of the tested and new developed materials at conditions closer to the SDE operating conditions and for longer period of time. 


\subsection{INTRODUCTION}

Thermochemical processes are being developed to provide global-scale quantities of hydrogen. Among the thermochemical processes, water electrolysis offers several advantages over other production methods. However, the technology and energy inputs for the electrolysis process can make the production of hydrogen by this method expensive Thermochemical water splitting cycles offer an alternate highly efficient route for the production of hydrogen [1]. Among the many possible thermochemical cycles for the production of hydrogen, the sulfur-based cycles lead the competition in overall energy efficiency.

A variant on sulfur-based thermochemical cycles is the Hybrid Sulfur (HyS) Process. The HyS cycle uses a sulfur dioxide-depolarized electrolyzer (SDE) to produce hydrogen. The electrolyzer oxidizes sulfur dioxide to form sulfuric acid at the anode [r1] and reduces protons to form hydrogen at the cathode [r2]. The overall electrochemical cell reaction consists of the production of $\mathrm{H}_{2} \mathrm{SO}_{4}$ and $\mathrm{H}_{2}$ [r3].

$$
\begin{gathered}
\mathrm{SO}_{2}+2 \mathrm{H}_{2} \mathrm{O} \rightarrow \mathrm{H}_{2} \mathrm{SO}_{4}+2 \mathrm{H}^{+}+2 e^{-} \\
2 \mathrm{H}^{+}+2 e^{-} \rightarrow \mathrm{H}_{2} \\
\mathrm{SO}_{2}+2 \mathrm{H}_{2} \mathrm{O} \rightarrow \mathrm{H}_{2} \mathrm{SO}_{4}+\mathrm{H}_{2}
\end{gathered}
$$

Original work on the development of a SDE featured a parallel-plate electrolyzer with a separator or membrane to keep the anolyte and catholyte compartments separate [2]. Since this work was completed in the early 1980s, significant advances have occurred in electrolyzer technology principally in the area of hydrogen fuel cells. Advanced hydrogen fuel cells employ proton conductive membranes with catalyst layers deposited on either side of the membrane, forming the respective anode and cathode of the electrochemical cell. The combination of membrane and electrode catalyst layers is referred to as the membrane electrode assembly or MEA.

We selected the fuel cell MEA design concept for the SDE in the HyS process [3]. The MEA concept provides a much smaller cell footprint than conventional parallel plate technology. The smaller footprint is a major benefit in scaling the electrolyzer to the size that will be required for commercial production. Key attributes of the SDE are high energy efficiency and long operating lifetime. To achieve high energy efficiency, the electrolyzer must exhibit rapid reaction kinetics at each electrode, little crossover of reagent and products across the membrane, and excellent chemical stability of each of the components to concentrated sulfuric acid solutions.

Task 1 of the FY06 HyS Project focused on identifying electrolyzer component materials and cell configurations that promote high energy efficiency and long operating lifetimes. Specific testing focused on evaluating commercially-available membranes for ionic resistance and sulfur dioxide transport characteristics, evaluating different electrocatalyst materials and evaluating different cell configurations. 


\subsection{EXPERIMENTAL}

\subsection{MEMBRANE PREPARATION}

A list of the tested membranes is shown in Table 1. During the selection process of commercially available membranes, an array of thicknesses, equivalent weights (EWs), chemistry, and reinforcements were considered. Preparation procedures of the membranes before testing were conducted according to the supplier's recommendations. Perfluorinated sulfonic acid (PFSA) membranes and non-fluorinated membranes such as Fumatech sulfonated poly-etherketone (SPEK) and Oxford Performance Materials (OPM) sulfonated poly-etherketone-ketone (SPEKK), were conditioned by washing in $0.5 \mathrm{M} \mathrm{H}_{2} \mathrm{SO}_{4}$ at $80{ }^{\circ} \mathrm{C}$ for one hour and rinsing in deionized water (DI-water) at $80{ }^{\circ} \mathrm{C}$ for another hour. Once treated, the membranes were stored in water until ready to use. Poly-benzimidazole type membranes (PBI) were rinsed with water before use.

Table 1. Evaluated Membranes

\begin{tabular}{ccccc}
\hline \hline ID & Manufacturer & Classification & $\begin{array}{c}\text { Thickness } \\
(\mu \mathbf{m})\end{array}$ & $\begin{array}{c}\text { Equivalent } \\
\text { Weight } \\
(\mathbf{g} / \mathbf{e q} .)\end{array}$ \\
\hline Nafion 117 & DuPont & PFSA & 180 & 1100 \\
\hline Nafion 115 & DuPont & PFSA & 130 & 1100 \\
\hline Nafion 112 & DuPont & PFSA & 50 & 1100 \\
\hline F-1460 & Fumatech & PFSA & 60 & 1400 \\
\hline F-1050 & Fumatech & PFSA & 50 & 1000 \\
\hline F-960 & Fumatech & PFSA & 60 & 900 \\
\hline Celtec-V & PEMEAS & PBI with immobilize & 50 & ---- \\
\hline Celtec-L & PEMEAS & PBI & 50 & ---- \\
\hline OXPEKK & OPM & SPEKK & 25 & N/A \\
\hline FKB & Fumatech & N/A & 80 & ---- \\
\hline E-750 & Fumatech & SPEK & 50 & 700 \\
\hline N-324 & DuPont & Reinforced PFSA & N/A & N/A \\
\hline \hline
\end{tabular}




\subsection{MEMBRANE CHARACTERIZATION}

The membrane ionic resistivity and $\mathrm{SO}_{2}$ transport were evaluated using a custom made permeation cell; a simplified schematic of the cell is shown in Figure 1. The cell consists of two glass chambers joined by a Teflon bridge where the membrane is secured. During measurements both chambers were filled with the concentrated acid of interest and purged of oxygen by flowing nitrogen. A three electrode system, which included a silver-silver chloride reference electrode $(\mathrm{Ag} / \mathrm{AgCl}, 196 \mathrm{mV}$ vs. standard hydrogen electrode (SHE)), a platinum flag as the counter electrode, and a platinum mesh as the working electrode, was used during measurements.

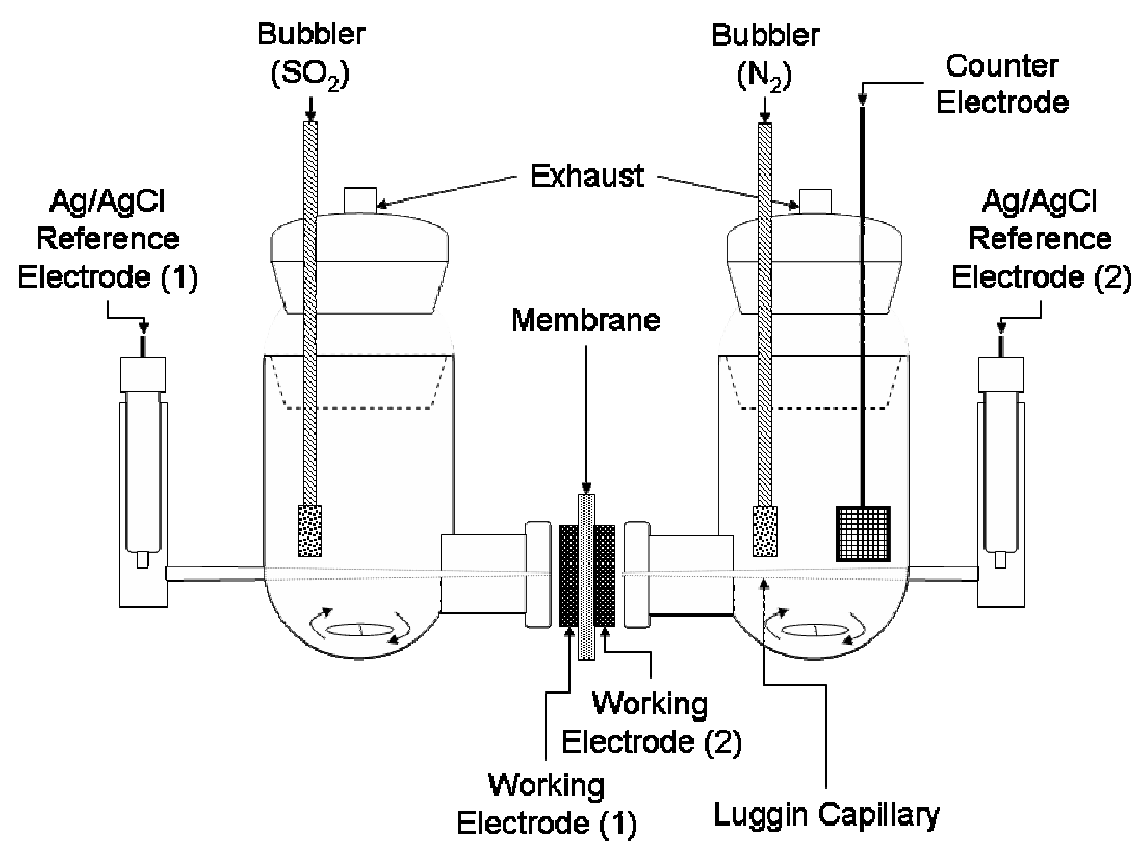

Figure 1. Simplified schematic of the membrane characterization cell

The Electrochemical Impedance Spectroscopy (EIS) technique was used to evaluate the ionic resistivity $(\rho)$ as a function of acid concentration. For this measurement, the working electrode and reference electrode were placed in position (1). After allowing several minutes for the membrane to equilibrate, a $10 \mathrm{mV}$ vs. OCP (open circuit potential) sinusoidal voltage was imposed across the membrane at frequencies between $100 \mathrm{kHz}$ and $200 \mathrm{~Hz}$. The resulting response was plotted in the form of Nyquist plots. The resistance was calculated from the value of the real impedance when the imaginary response is zero. The resistivity was calculated with the following equation,

$$
\rho=\frac{Z_{\text {real }} A}{L}
$$

where ' $L$ ' is the thickness of the membrane, ' $A$ ' is the area available for proton conduction, and ' $Z_{\text {real }}$ ' is the real part of the impedance response when the imaginary impedance is zero. A potentiostat/frequency analyzer from Gamry was used for this measurement. 
The $\mathrm{SO}_{2}$ transport was monitored by measuring the current as a function of time while a constant potential is applied. For the $\mathrm{SO}_{2}$ transport, the reference and working electrodes were rearranged in position (2). The cell was filled with $30 \mathrm{wt} . \% \mathrm{H}_{2} \mathrm{SO}_{4}$ and purged with $\mathrm{N}_{2}$. A constant potential of $1040 \mathrm{mV}$ vs. SHE was applied on the working electrode while the current was measured as a function of time. Once the background current became close to zero, the flowing of $\mathrm{SO}_{2}$ was started on the left chamber. The $\mathrm{SO}_{2}$ permeating through the membrane was oxidized to sulfuric acid by the working electrode. A Bioanalytical Systems (BAS) B/W electrochemical analyzer was used to measure the current responses as a function of time.

\subsection{CATALYST CHARACTERIZATION}

The catalyst activity and stability was evaluated using the three electrode cells shown in Figure 2. The cell consists of a glass vial with a Teflon cap. The three electrodes, which included a silver-silver chloride reference electrode, a platinum wire as the counter electrode, and a glassy carbon disk electrode, were inserted through the Teflon cap.

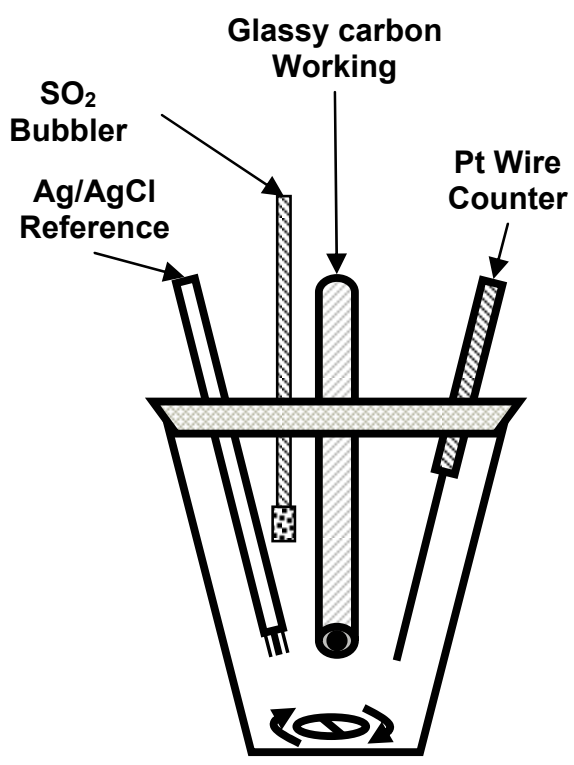

Figure 2. Simplified schematic of the catalyst characterization cell

During measurements the vial was filled with concentrated acid and purged of oxygen by flowing nitrogen. The catalyst's electrochemical characterization consisted of cyclic voltammograms (CVs) in the solution purged with nitrogen and linear sweep voltammograms (LSVs) in $\mathrm{SO}_{2}$ saturated sulfuric acid solutions. The CVs were performed at a scan rate of $50 \mathrm{mV} / \mathrm{sec}$. and in a potential window between $1004 \mathrm{mV}$ and $-100 \mathrm{mV}$ vs. $\mathrm{Ag} / \mathrm{AgCl}$. The LSVs were performed in the potential window between $804 \mathrm{mV}$ and $104 \mathrm{mV}$ vs. $\mathrm{Ag} / \mathrm{AgCl}$ at a scan rate of $5 \mathrm{mV} / \mathrm{sec}$. The curves were repeated until a stable performance was obtained. Both measurements were performed starting from the anodic potential and going in the cathodic direction. 


\subsection{RESULTS AND DISCUSSION}

\subsection{SULFUR DIOXIDE TRANSPORT}

In a perfectly efficient $\mathrm{SDE}$, all of the $\mathrm{SO}_{2}$ is oxidized to sulfuric acid [r1]. In practice, the cell is not $100 \%$ efficient and some of the $\mathrm{SO}_{2}$ migrates from the anolyte side through the membrane into the catholyte side of the cell. Migration of the neutral $\mathrm{SO}_{2}$ species largely arises by diffusion driven by the concentration gradient from the anolyte to the catholyte. Upon reaching the cathode, $\mathrm{SO}_{2}$ can be reduced to produce sulfur and sulfides. Reduction of the $\mathrm{SO}_{2}$ decreases the electrical efficiency of the cell. The $\mathrm{SO}_{2}$ transport to the cathode not only affects the purity of the hydrogen being produced, but the long term effects of these impurities incorporated in the membrane, cathode catalyst, or diffusion layer are not yet known.

Thus, a separator with high ionic conductivity, low minimal $\mathrm{SO}_{2}$ transport, and long term stability is needed. The current design for the SDE is based on a polymer electrolyte membrane fuel cell (PEMFC). The Nafion ${ }^{\circledR}$ family of perfluorinated sulfonic acid membranes is an attractive candidate membrane due to its relatively high ionic conductivity and chemical stability in strong acid solutions. However, previous testing indicated fairly high $\mathrm{SO}_{2}$ transport to the cathode.

A review of the literature revealed a number of commercially available membranes that may be suitable for use in the SDE. Table 1 provides the list of membranes that we selected for testing the $\mathrm{SO}_{2}$ transport and ionic conductivity. The first group of membranes selected was the PFSA family membranes which have been developed for PEM fuel cells for operation at low temperatures $\left(80{ }^{\circ} \mathrm{C}\right)$. The properties of the PFSA type membrane with $\mathrm{EW}=1100$ is considered in this work report as the baseline to which the non-PFSA membranes will be compared. Membranes developed for DM fuel cells such as SPEKK and SPEK are studied in this work due to their improved properties to reduce the crossover of methanol and their ability to operate at higher temperatures (up to $140{ }^{\circ} \mathrm{C}$ ). Finally membranes originally developed for PA fuel cells from the PBI family were selected for their ability to operate at temperatures up to their $200{ }^{\circ} \mathrm{C}$ under dry conditions. Unlike the sulfonated type of membranes (PFSA, SPEKK or SPEK) that employ sulfonic acid groups to transport hydrated protons, these PBI membranes employ a mechanism (hopping mechanism) in which immobilized anions create a network for proton transfer.

The permeation rate of $\mathrm{SO}_{2}$ species through the membranes was monitored by an electrochemical technique (see experimental section). The flux profile contains three distinct regions. First at time close to -0 -, the currents are flat indicating the concentration build up in the chamber. As $\mathrm{SO}_{2}$ flows in the chamber a concentration gradient is created and the driving force for $\mathrm{SO}_{2}$ to permeate through the membrane is increased, this creates the second region. At this point the $\mathrm{SO}_{2}$ that is transported to the other side of the membrane is oxidized by the working electrode and permeation current is recorded. In the third region, the steady state flux is reached and no change in the flux is observed. By assuming that all $\mathrm{SO}_{2}$ 
transported reacts according to [r1] we can obtain the $\mathrm{SO}_{2}$ flux, $J_{\mathrm{SO}_{2}}$, from the electrical response using Faraday's Law,

$$
J_{\mathrm{SO}_{2}}=\frac{i}{n F}
$$

where ' $i$ ' is the current density in $\mathrm{A} / \mathrm{cm} 2$, ' $F$ ' is Faraday's constant (96,487 C/eq.), and ' $n$ ' is the number of electrons transferred.

The $\mathrm{SO}_{2}$ flux through the different membrane samples can be observed in Figures 3 and 4 for PFSA and non-PFSA type of membranes respectively. All samples developed a well defined steady state current region with the exception of N112. In this case a fluctuating noise was developed when approaching higher oxidation currents $\left(3^{\text {rd }}\right.$ region). The noise is caused by the formation of gas bubbles which creates a disturbance in the $\mathrm{SO}_{2}$ diffusion layer developed between the membrane and the working electrode. Such high $\mathrm{SO}_{2}$ flux observed makes N112 and other membrane samples, such as F-1050 and F-960 (not shown in this work), unacceptable for an SDE.

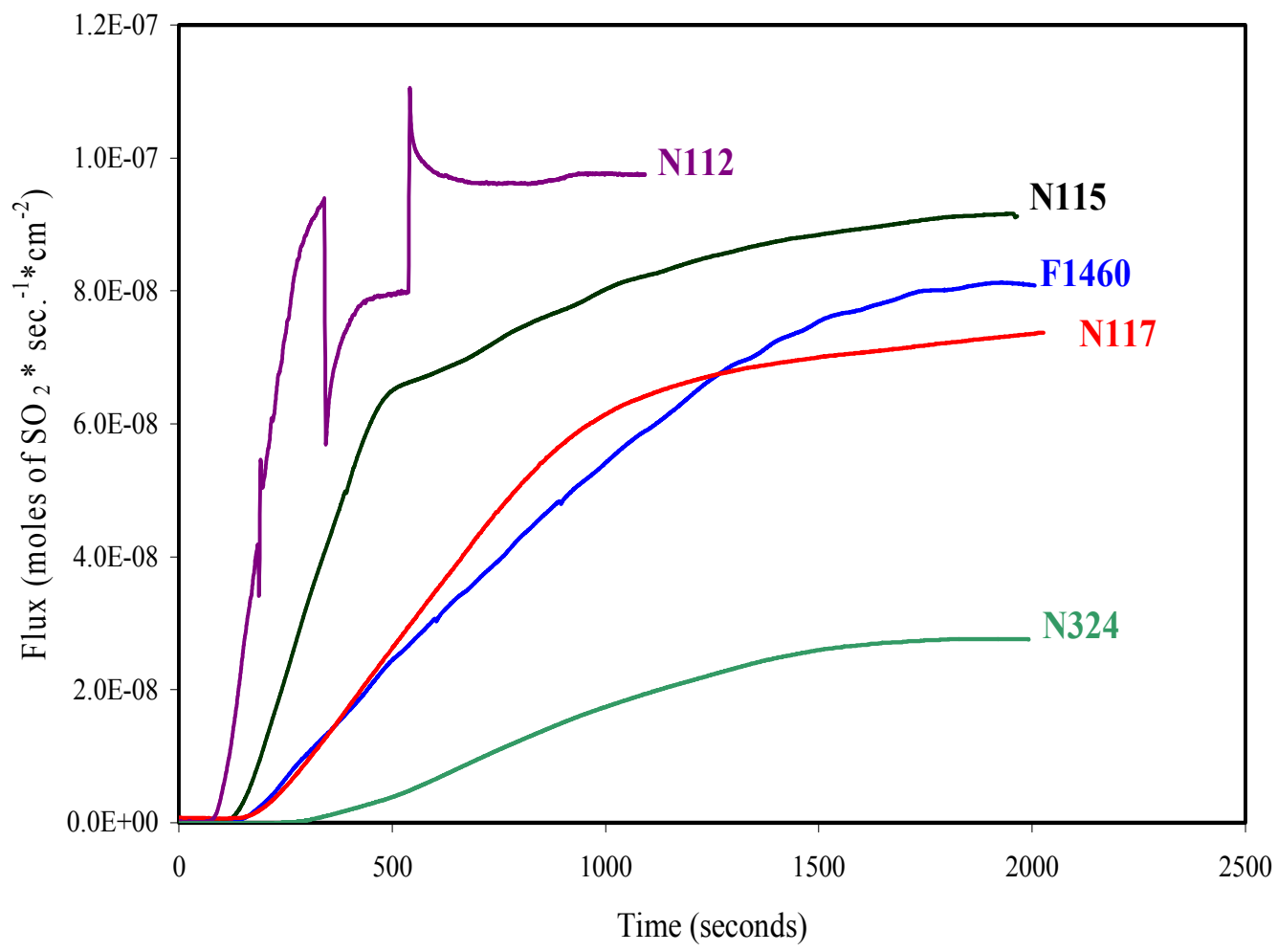

Figure 3. $\mathrm{SO}_{2}$ transport through PFSA membranes immersed in 30 wt.\% $\mathrm{H}_{2} \mathrm{SO}_{4}$ saturated with $\mathrm{SO}_{2}$ at room temperature. Working electrode set at $1040 \mathrm{mV}$ vs. SHE 


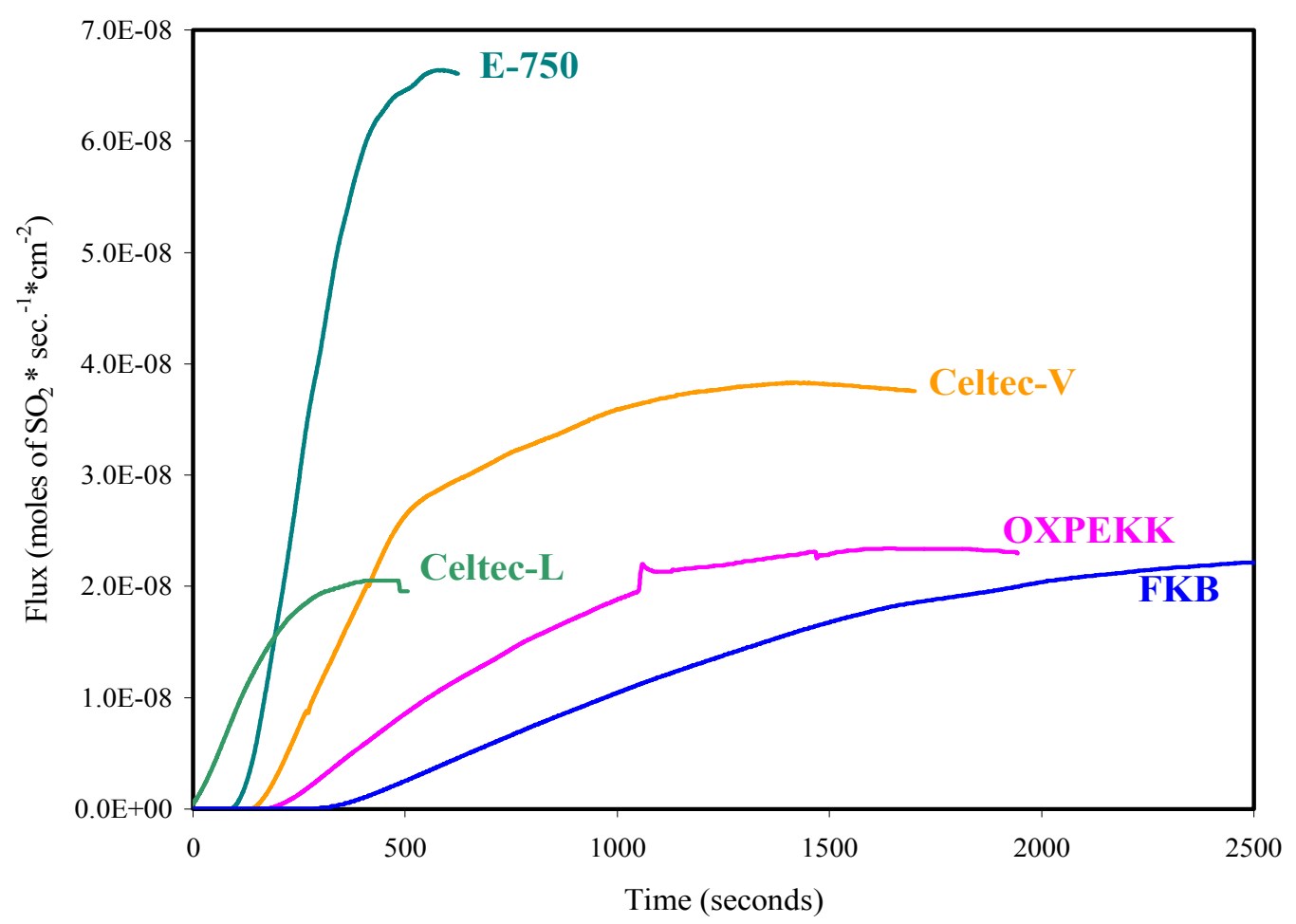

Figure 4: $\mathrm{SO}_{2}$ transport through non-PFSA membranes immersed in $30 \mathrm{wt} \% \mathrm{H}_{2} \mathrm{SO}_{4}$ saturated with $\mathrm{SO}_{2}$ at room temperature. Working electrode set at $1040 \mathrm{mV}$ vs. SHE

The $J_{\mathrm{SO}_{2}}$ through a membrane can be described by Fick's law of diffusion, where the thickness, ' $L$ ', of the membrane and the diffusion coefficient, ' $D$ ', will play an important role on the flux. At steady state conditions and assuming that all $\mathrm{SO}_{2}$ transported through the membrane is oxidized at the membrane surface, Fick's first law of diffusion can be simplified and used to calculate ' $D$ ',

$$
J_{\mathrm{SO}_{2}}=\frac{D C_{0}}{L}
$$

where ' $C_{0}$ ' is the bulk concentration of $\mathrm{SO}_{2}$ (estimated value $1.09 \mathrm{M}$ ) and ' $L$ ' is the thickness of the membrane. Figure 3 shows the flux through the membranes from the PFSA family with the main differences being the thickness and amount of sulfonic acid groups. The dependence on the thickness can be observed in the figure by comparing the flux through N112, N115, and N117. As expected, the flux is maximum for N112 and followed by N115 and N117. The effect of the concentration of sulfonic acid groups on the flux is mainly caused by a change in the diffusion coefficient. It is well known that when PFSA polymers hydrate, water binds to the ionic groups to produce a fully separate phase with concentrated ionic domains. This domain contains channels where neutral species that dissolve in water can diffuse. As a consequence, a membrane with the same thickness but higher EW will transport less $\mathrm{SO}_{2}$ than a material with lower EW. The effect of the amount of conductive 
groups on the flux can be observed by comparing N112 (EW=1100 g/eq) and F-1460 (1400 $\mathrm{g} / \mathrm{eq})$. For the PFSA type membranes, the lowest flux is observed for N324 and followed by N117.

Non-PFSA membranes are being developed worldwide as substitutes for PFSA membranes used in fuel cells. At the moment these alternative membranes show superior properties such as high temperature operation and better barrier properties, but lack the high ionic conductivity of PFSA type membranes. The results for non-PFSA membranes are plotted in Figure 4. The overall performance of these thinner membranes in comparison to PFSA is remarkable. The $\mathrm{SO}_{2}$ flux was reduced almost an order of magnitude. Among the possible reasons for the reduction of $\mathrm{SO}_{2}$ flux is the use of polymers with stiffer backbones that will prevent the phase separation and the formation of ionic acid domains [4]. Among the membranes tested, OXPEKK showed the lowest flux followed by FKB and Celtec-L. Figure 5 shows the steady state $J_{\mathrm{SO}_{2}}$ for all of the tested membranes.

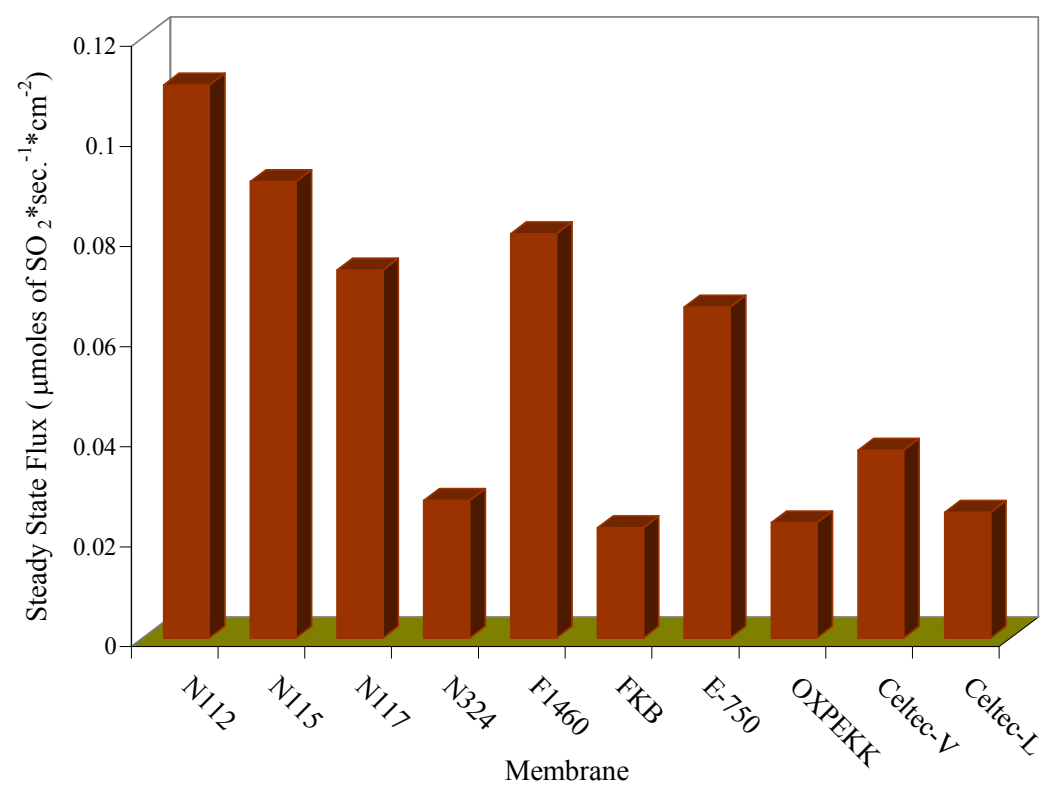

Figure 5: Steady state $\mathrm{SO}_{2}$ flux through the tested membranes immersed in 30 wt.\% $\mathrm{H}_{2} \mathrm{SO}_{4}$ saturated with $\mathrm{SO}_{2}$ at room temperature. Working electrode set at $1040 \mathrm{mV}$ vs. SHE. 


\subsection{IONIC RESISTANCE}

In order to produce hydrogen in the most efficient way, the SDE operation voltage must be kept low while the operating currents remain high. This will give us a high hydrogen production while keeping the power going in to the SDE operation low. To help achieve this goal a separator with high proton conductivity is necessary to help reduce the inefficiencies of the system. The proton conductivity of the different membrane materials was measured by means of the EIS technique. An example of the raw data plotted in a Nyquist is shown in Figure 6.

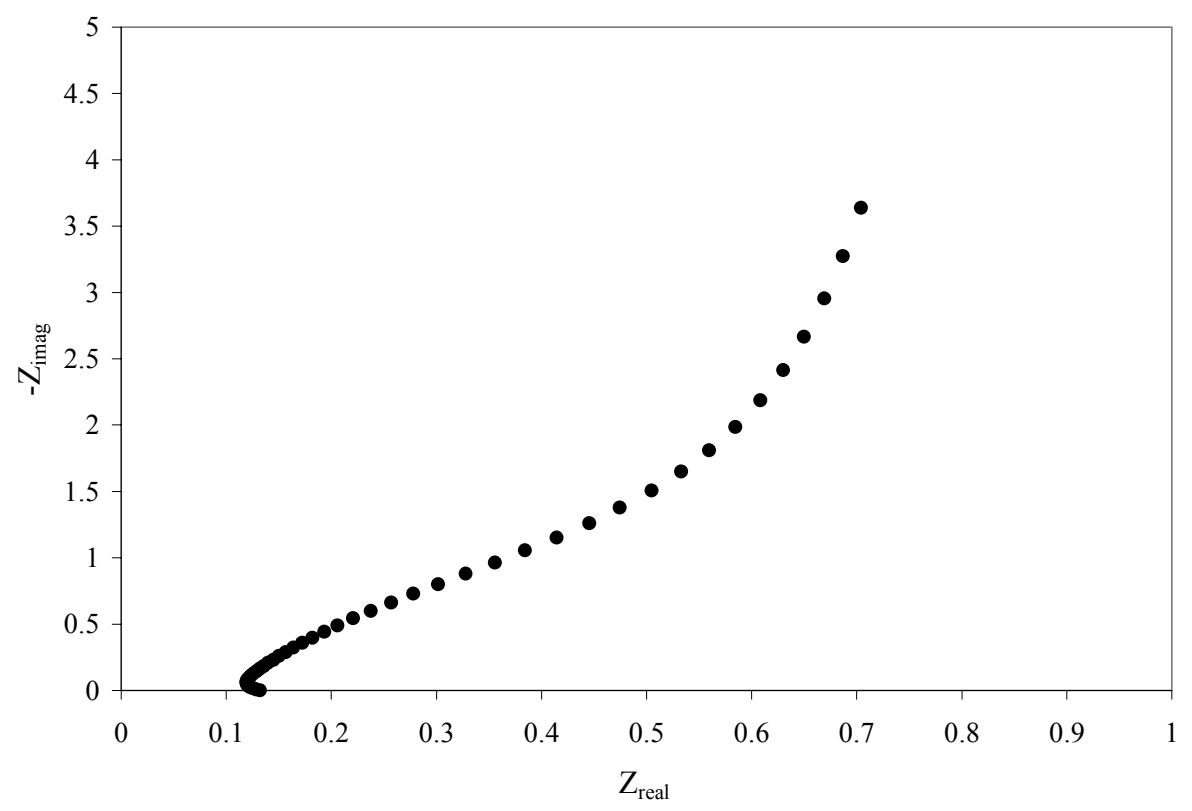

Figure 6. Impedance response of a typical proton conducting membrane in $30 \mathrm{wt} . \%$ $\mathrm{H}_{2} \mathrm{SO}_{4}$ purged with $\mathrm{N}_{2}$ at room temperature.

The ionic resistance was calculated from [eq1] and plotted in Figure 7 in terms of proton conductivity for each membrane. The conductivity of most of the tested samples is in the same range, except for the Nafion ${ }^{\circledR}$ samples which shows the highest proton conductivity. The conductivity of N324 (reinforced PFSA membrane) was omitted from the figure due fact that the effective surface area and effective thickness was not known due to the reinforcement material. Aside from Nafion ${ }^{\circledR}$, Celtec-L membrane shows the next to highest conductivity. 


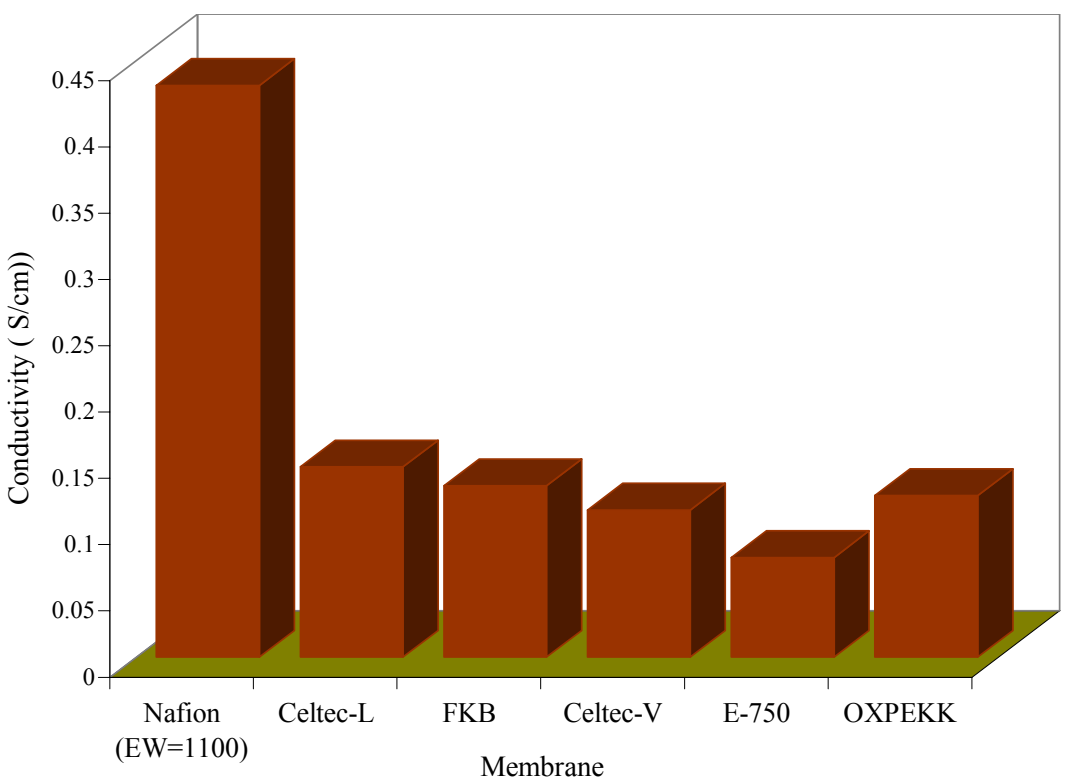

Figure 7. Proton conductivity in 30 wt. $\% \mathrm{H}_{2} \mathrm{SO}_{4}$ purged with $\mathrm{N}_{2}$ at room temperature.

From the view point of proton conductivity, the Nafion ${ }^{\circledR}$ membranes are superior to the other membranes; however, the thickness of the membrane needed in order to have low $\mathrm{SO}_{2}$ transport needs to be considered. Table 2 compares the ionic conductance and the diffusion coefficient of $\mathrm{SO}_{2}$ in the membranes. When the thickness of the Nafion ${ }^{\circledR}$ membranes is taken in consideration, such as in the case of N117, an averaged conductance is obtained. In order to further reduce the $\mathrm{SO}_{2}$ transport to more acceptable values, a thicker membrane than N117 will be needed. The OXPEKK membrane exhibited the highest ionic conductance and lowest diffusion coefficient, but this material losses mechanical integrity when pretreated at $80^{\circ} \mathrm{C}$ in $0.5 \mathrm{M} \mathrm{H}_{2} \mathrm{SO}_{4}$. Therefore, is not a particularly attractive candidate membrane for the SDE. The Celtec-L membrane, which is a PBI-based membrane, offered relativity good ionic conductance and a lower diffusion coefficient compared to the Nafion ${ }^{\circledR}$ membrane, and, thus, warrants further consideration for use in the SDE.

Table 2. Comparison of diffusion coefficient and ionic resistance in evaluated membranes

\begin{tabular}{ccc}
\hline \hline ID & $\begin{array}{c}\text { Diffusion Coefficient } \\
\left(\mathbf{c m}^{\mathbf{2}} / \mathbf{s}\right)\end{array}$ & $\begin{array}{c}\text { Ionic Conductance } \\
\left(\mathbf{S}_{-}-\mathbf{c m}^{\mathbf{2}}\right)\end{array}$ \\
\hline $\mathrm{N} 117$ & $1.21 \times 10^{-6}$ & 24.0 \\
\hline $\mathrm{F}-1460$ & $4.45 \times 10^{-7}$ & ---- \\
\hline Celtec-V & $1.72 \times 10^{-7}$ & 22.2 \\
\hline Celtec-L & $1.15 \times 10^{-7}$ & 28.7 \\
\hline OXPEKK & $5.28 \times 10^{-8}$ & 48.8 \\
\hline FKB & $1.61 \times 10^{-7}$ & 16.2 \\
\hline E-750 & $3.03 \times 10^{-7}$ & 15.0 \\
\hline N-324 & ---- & 24.8 \\
\hline \hline
\end{tabular}




\subsection{CATALYST CHARACTERIZATION}

Selecting the right catalyst will have an impact on the electrical efficiency by allowing the SDE to operate at conditions closer to the reversible potential ( $0.17 \mathrm{~V}$ vs. SHE) and will have an influence in helping achieve a long term stable performance. Two types of catalysts will be needed, one for the anode and one for the cathode. At the cathode, the electrochemical reaction [r2] occurs at higher rates than reaction [r1] and at the reversible potential of $0 \mathrm{~V}$ vs. SHE. The catalyst of choice is platinum supported on carbon. However, some $\mathrm{SO}_{2}$ is transported through the membrane to the cathode where the $\mathrm{SO}_{2}$ is reduced to elemental sulfur. This parasitic reaction not only decreases the hydrogen production efficiency, but it also tends to deposit all over the cathode, causing long term effects that are not fully understood yet. Some ways of directly reducing this side reaction are to have a higher $\mathrm{SO}_{2}$ utilization at the anode and use less permeable membranes, therefore reducing the amount of reactant reaching the catalyst layer. On the other hand, the kinetics for the electrochemical oxidation of $\mathrm{SO}_{2}$ at the anode are very slow and most of the inefficiencies of the electrolyzer arise from the low kinetics for reaction [r1]. The selection of a more active anode catalyst from commercially available catalysts was considered to be the main focus of this section.

Consecutive CVs were performed to study the stability of the catalyst and the different electrochemical reactions occurring at the surface of the electrode in the absence of $\mathrm{SO}_{2}$. During the CVs the current was monitored as a function of a set potential which is varied at a constant rate. Figure 8 shows the consecutive CVs for Pt supported on carbon $(\mathrm{Pt} / \mathrm{C}, 45$ wt.\% Pt) and $\mathrm{Pd}$ supported on carbon $(\mathrm{Pd} / \mathrm{C}, 40 \mathrm{wt} . \% \mathrm{Pd})$ measured at different acid concentrations and in the absence of $\mathrm{SO}_{2}$. Similar behavior was obtained for both materials. The high potential peak shows the monolayer oxide formation-reduction of the catalyst layer in $30 \mathrm{wt} . \% \mathrm{H}_{2} \mathrm{SO}_{4}$ is observed at around $0.75 \mathrm{~V}$ vs. SHE for Pd and $0.8 \mathrm{~V}$ vs. SHE for Pt. As the acid concentration is increased, the peak intensity for the oxide formation decreases indicating the formation of oxides is more limited. The low potential peak in the potential region between 0.24 and $0.1 \mathrm{~V}$ vs. SHE corresponds to the hydrogen adsorption-desorption on the catalyst surface. Contrary to the metal oxidation peak at high potentials, as the acid strength increases the intensity of the hydrogen adsorption-desorption peak increases. 

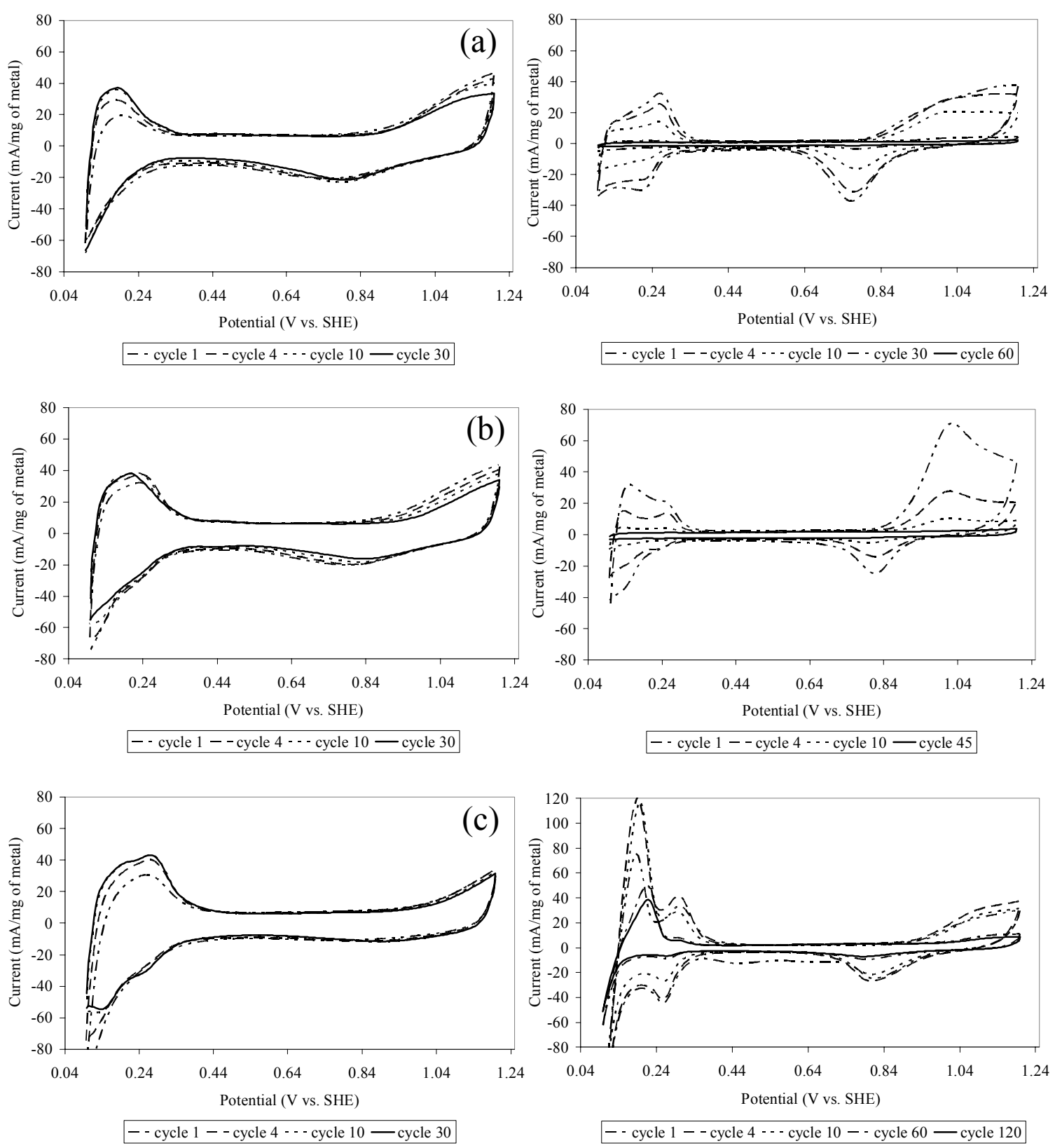

Figure 8. Cyclic voltammograms after consecutive cycling for $\mathrm{Pt} / \mathrm{C}$ (left) and $\mathbf{P d} / \mathrm{C}$ (right) in 30 wt.\% (a), 50 wt.\% (b), and 70 wt.\% (c) $\mathrm{H}_{2} \mathrm{SO}_{4}$ purged with $\mathrm{N}_{2}$ at room temperature.

In general the area under the hydrogen adsorption-desorption peak gives an idea of the electrochemically active surface area available for reaction. A reduction in the surface area indicates that the metal particles are either agglomerating on the carbon surface or the metal catalyst is not stable in the solution and is dissolving. In the case of the $\mathrm{Pt} / \mathrm{C}$ catalyst, the peak tends to increase until it stabilizes. This initial increase corresponds to the initial wetting by the electrolyte of the catalyst surface. In the case of Pd the surface area tends to decrease with each cycle until no peaks are observed. An interesting behavior on the CVs is observed when $\mathrm{Pd} / \mathrm{C}$ catalyst is cycled in $70 \mathrm{wt} . \% . \mathrm{H}_{2} \mathrm{SO}_{4}$. Besides the hydrogen adsorption- 
desorption peak being three times larger than in the previous cases, the peak height decreases as a function of cycle but it stabilizes and doesn't completely disappear. The difference in the hydrogen desorption peak height after consecutive cycling can be observed in Figure 9.
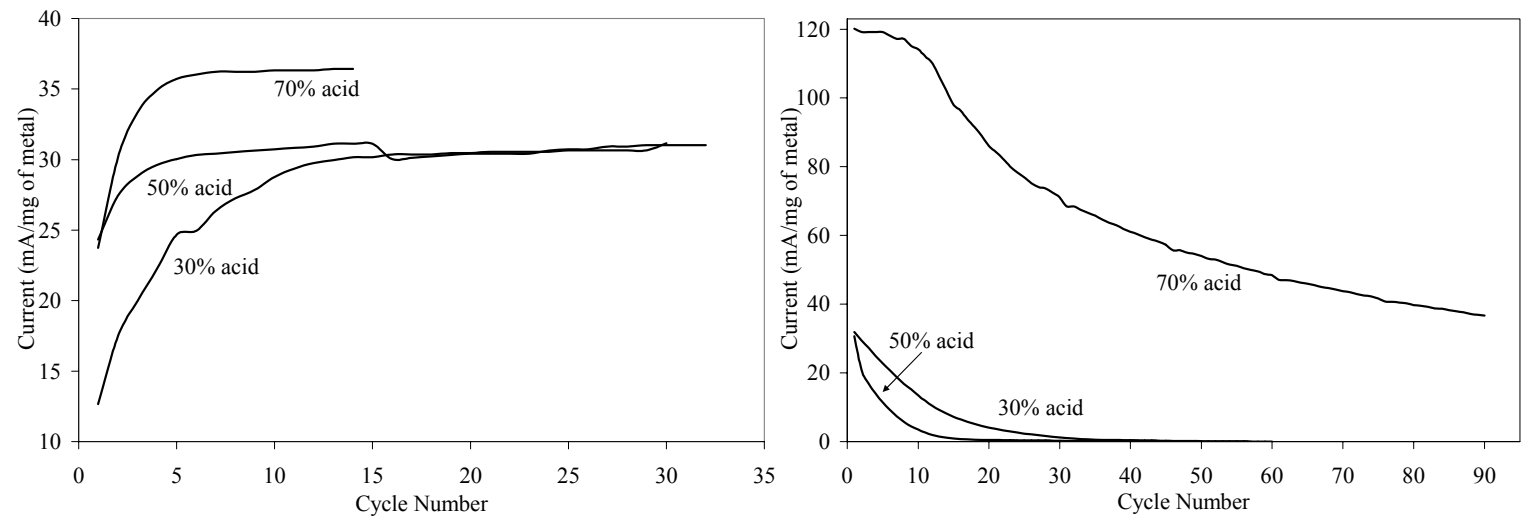

Figure 9. Hydrogen desorption peak height after consecutive cycling (see Figure 8) for $\mathrm{Pt} / \mathrm{C}$ (left) and $\mathrm{Pd} / \mathrm{C}$ (right) in sulfuric acid purged with $\mathrm{N}_{2}$ at room temperature.

The electrocatalytic activity of the $\mathrm{Pt} / \mathrm{C}$ and $\mathrm{Pd} / \mathrm{C}$ catalysts was investigated for the oxidation of $\mathrm{SO}_{2}$ in sulfuric acid solutions at room temperature. The potential current relationship is shown in Figure 10 in the form of Tafel plots. It can be seen from the plots how the open circuit voltage increases as the acid strength increases, for example for $\mathrm{Pt} / \mathrm{C}$ and $\mathrm{Pd} / \mathrm{C}$ at 30 wt. $\% \mathrm{H}_{2} \mathrm{SO}_{4}$ a potential of $0.50 \mathrm{~V}$ and $0.59 \mathrm{~V}$ vs. SHE is observed while a potential of $0.61 \mathrm{~V}$ and $0.70 \mathrm{~V}$ vs. SHE in 70 wt. $\% \mathrm{H}_{2} \mathrm{SO}_{4}$ respectively. It is noted that the currents are also higher for the samples immersed in lower acid strength, however at high potentials the currents obtained in $50 \mathrm{wt} . \% \mathrm{H}_{2} \mathrm{SO}_{4}$ approach those obtained for $30 \mathrm{wt} . \% \mathrm{H}_{2} \mathrm{SO}_{4}$. Although the stability of the $\mathrm{Pd}$ samples seems to improve with the use of $70 \mathrm{wt} \% \mathrm{H}_{2} \mathrm{SO}_{4}$, the kinetic activity proves to be too poor to be considered for an SDE. In view of the kinetic results, the overall performance and stability of the $\mathrm{Pt}$ catalyst is superior to that of $\mathrm{Pd}$ catalysts. It is also shown that the use of acid concentrations higher than 50 wt. $\% \mathrm{H}_{2} \mathrm{SO}_{4}$ will decrease the $\mathrm{SDE}$ power efficiency by increasing the $\mathrm{SO}_{2}$ oxidation overvoltage.
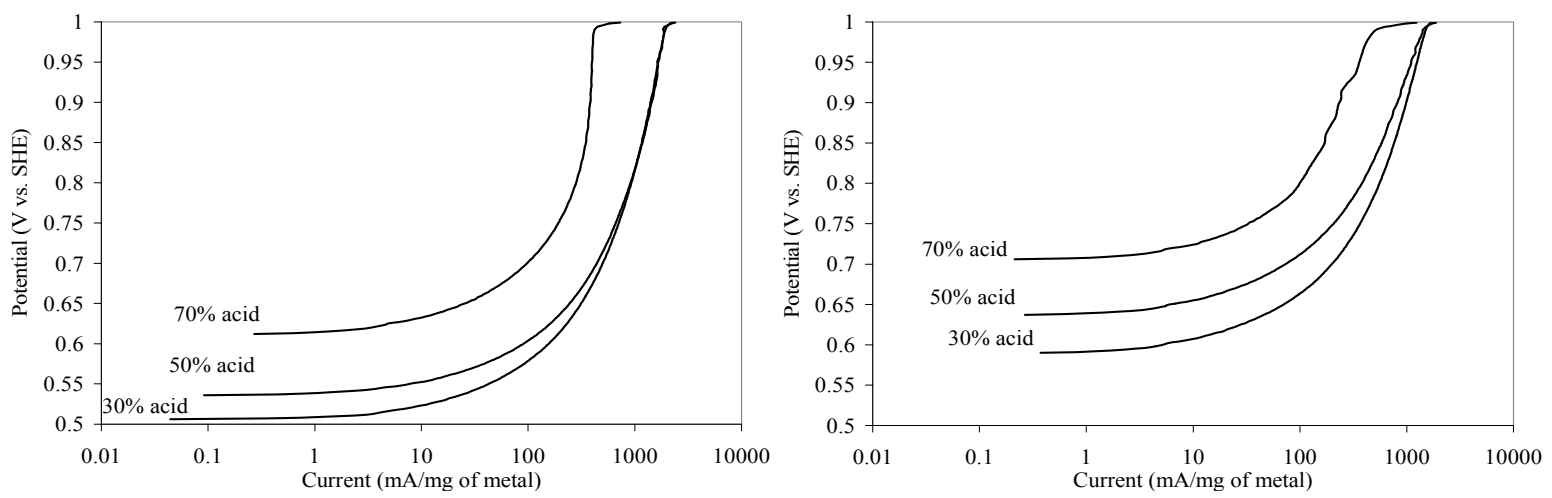

Figure 10. Tafel plots for $\mathrm{SO}_{2}$ oxidation on $\mathrm{Pt} / \mathrm{C}$ (left) and $\mathrm{Pd} / \mathrm{C}$ (right) in sulfuric acid saturated with $\mathrm{SO}_{2}$ at room temperature. 


\subsection{CELL DESIGN}

An important factor in the development of a successful SDE is the way the individual components are incorporated. An improper assembly will lead to an electrolyzer with high electrical inefficiencies. The simplest electrolyzer design will consist of three basic components. Figure 11 (a) shows a simplified schematic of the basic units in the SDE. Starting on both extremes the flow fields are encountered. The flow field's role is to collect the electrons and to allow easy access of the reactants and products to all parts of the electrolyzer. The flow field will also play an important role in the heat management in order to avoid hot or cold spots.

Next to the flow fields is the diffusion media. The diffusion media is one of the most critical components in achieving good performance in the SDE; its duties include current collector, transport media and support for the catalyst layers. Generally the diffusion media consists of two layers. The first layer, or the backbone of the diffusion layer, consists of a conductive paper or cloth that provides structural integrity and macro-pores to aid in the diffusion of reactants and products. The second layer or micro-porous layer refines the surface of the first layer by using a thin smooth carbon layer that decreases the contact resistance between the catalyst layer and the first layer while allowing the diffusion of species in and out of the catalyst layer.

The micro-porous layer finds its use in gas phase feeds, however when the reactants are liquid the micro-porous layer adds a mass transfer resistances to the system. In the heart of the electrolyzer the MEA is found. The MEA consists of a membrane coated with a catalyst layer on both sides. Figure 11 (b) shows a scanning electron microscope (SEM) image of an MEA. The catalyst layer composition consists of the catalyst powder bonded with solid electrolyte. The solid electrolyte can be either of the same MEA membrane material or any other electrolyte with high ionic conductivity and high reactant diffusivity. According to the results in sections 4.1 and 4.2 Nafion $^{\circledR}$ shows the desired properties for the catalyst layer binder/electrolyte.

There are two main procedures for MEA preparation, catalyst coated electrode (CCE) and catalyst coated membrane (CCM). For the CCE preparation, a catalyst ink (catalyst powder, liquid polymer electrolyte and solvent) is deposited on the micro-porous layer of the diffusion layer. When the ink is dry, the electrode is bonded on to the membrane using a heated press. The use of the CCE process requires the use of a diffusion layer with a microporous layer, therefore reducing the flexibility of the diffusion layers that can be studied. On the CCM preparation, the catalyst ink is deposited on the membrane itself. This method allows for a wider variety of diffusion layers with or without the micro-porous layer. Usually the catalyst layer deposited with this method tends to be more compact and the catalyst utilization is higher.

During this task, three different types of MEAs were prepared. The first type was considered as the baseline and the design was identical to that used in a PEM fuel cell. The MEA was prepared using the CCE method, N115 membrane was heat pressed with the catalyst layer (Nafion and Pt/C) loaded on carbon cloth. The second and third MEA were prepared by the 
CCM method. The second MEA design was an improvement of the first according to the feed back received from the testing engineers. On the second design, the catalyst layer (Nafion and $\mathrm{Pt} / \mathrm{C}$ ) was deposited on $\mathrm{N} 117$, and carbon paper without the micro-porous layer was used. This design showed great improvement in the performance of the SDE. The final MEA design was prepared following the same procedure and diffusion materials as the second MEA with the only difference being the use Celtec-L membrane/separator instead of N117. This last MEA is expected to reduce the $\mathrm{SO}_{2}$ crossover and improve the ionic conductivity.

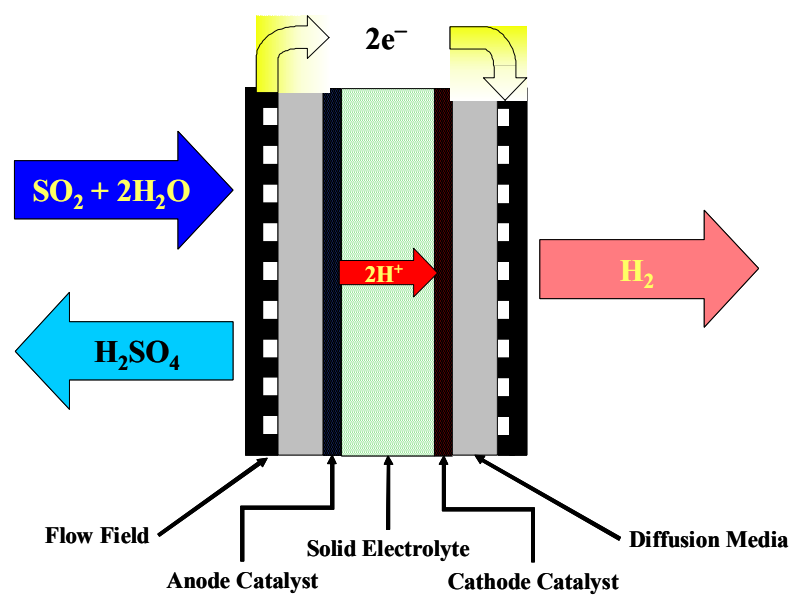

(a)

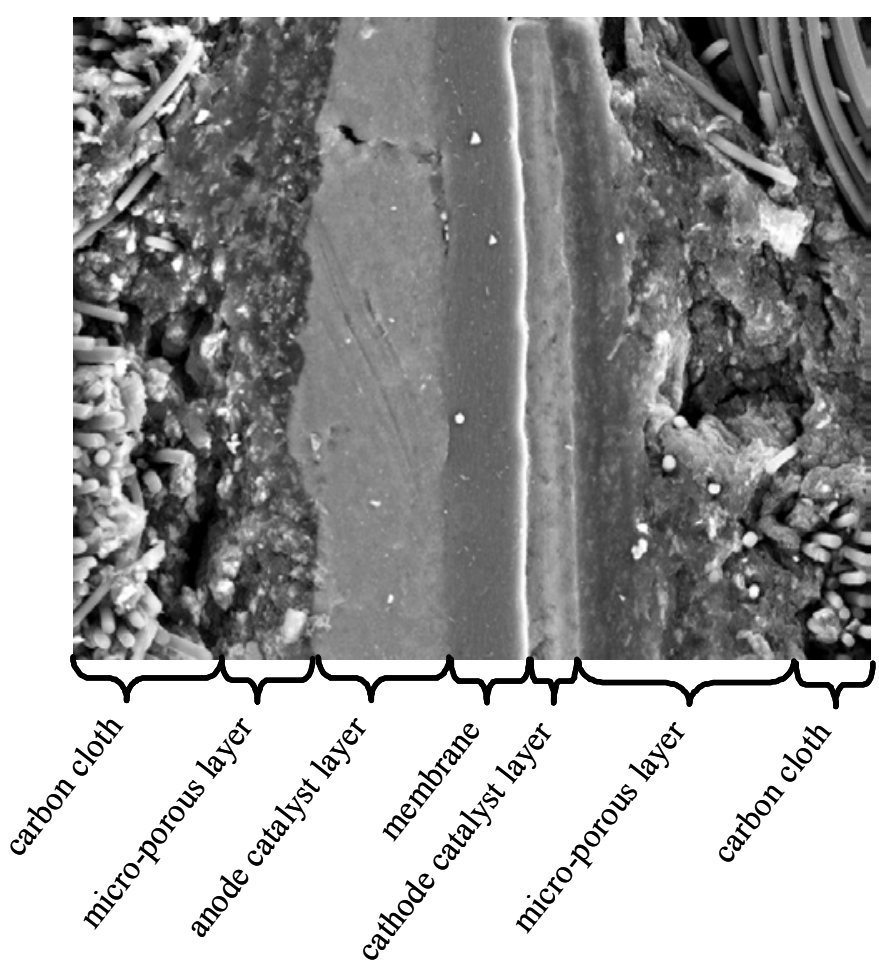

(b)

Figure 11. Simplified schematic of the SDE and the processes taking place (a) and SEM image of the MEA (b). 


\subsection{CONCLUSIONS AND RECOMMENDATIONS}

The $\mathrm{SO}_{2}$ transport and ionic conductivity was studied on commercially available cationic membranes used mainly in low temperature fuel cells. It is desired for the SDE to have a membrane with a low diffusion coefficient, but high proton conductivity. The membranes from the SPEKK family showed the lowest diffusion coefficient and highest conductance among the tested samples; however its mechanical integrity was low when the membrane was pretreated. Membranes from the PBI-family, such as Celtec-L, followed by membranes from the PEEK family, such as FKB, showed next to best performance. PFSA type membranes showed the highest ionic conductivity and diffusion coefficient, suiting this type of solid electrolyte for the development of the catalyst layers in the MEA.

The catalytic activity and stability of $\mathrm{Pt} / \mathrm{C}$ and $\mathrm{Pd} / \mathrm{C}$ was studied in sulfuric acid solutions at room temperature. The results showed that $\mathrm{Pd}$ catalyst is unstable in the testing conditions, while Pt showed very good stability. Tafel plots of Pt showed a $100 \mathrm{mV}$ improvement for the oxidation of $\mathrm{SO}_{2}$ over the Pd catalyst. It also was observed that the kinetics for $\mathrm{SO}_{2}$ oxidation begin to dramatically decrease when the acid strength is increased to values higher than 50 wt.\%.

The different MEA preparation procedures combined with different diffusion layer were analyzed. Three types of MEAs were developed for the SDE testing. First design consisted of PEM fuel cell MEA prepared by the CCE method (N115 as the membrane). According to the results from its test, the preparation was changed to a CCM preparation method with carbon paper on both sides and N117 as the membrane. Being this second design successful, a third MEA was prepared with the same procedure and materials except that the membrane tested was changed to the best performing membrane from the membrane characterization studies, Celtec-L.

The evaluation results of commercially available membranes for PEM fuel cell indicated that some membranes where able to lower the $\mathrm{SO}_{2}$ transport better than others while maintaining high conductivity values. However the evaluation process did not looked at the stability of the membranes for long periods of time at conditions that simulate the SDE operation.

The short-term activity and stability of the anode catalysts showed that $\mathrm{Pt}$ is by far a superior catalyst to the other materials tested. Nevertheless, the starting potential for the $\mathrm{SO}_{2}$ oxidation reaction on the $\mathrm{Pt}$ surface is $\sim 320 \mathrm{mV}$ higher than that of the thermodynamic potential. This higher voltage will translate in higher power inputs to the SDE operation. The need of catalyst that will offer better kinetic (lower over-voltage) is crucial for the production of hydrogen in more efficient and cost effective process. In this work it was also overlooked the cathode catalyst for the hydrogen recombination step. The possibility of a cathode catalyst with the high kinetics of the Pt catalysts but immune to the reduction of $\mathrm{SO}_{2}$ needs to be explored.

Even thou the results presented here answer many questions and provide guidance about the materials to be used in the electrolyzer, it also present more questions about the performance 
of the suggested membranes at conditions that simulate more closely the SDE operating conditions. The conditions include long term operation conditions at higher acid concentrations and temperatures. The study of new materials (such as hybrid membranes or newly developed membranes and Pt alloys on different supports) tailored for the SDE is a necessary step to make a reality the method for the production of an efficient and clean fuel. 


\section{0 REFERENCES}

[1] P. Sivasubramanian, R. P. Ramasamy, F. J. Freire, C. E. Holland and J. W. Weidner, 2005, "Electrochemical Hydrogen Production from Thermochemical Cycles using a Proton Exchange Membrane Electrolyzer", Int. J. hydrogen Energy, article submitted.

[2] Westinghouse Electric Corporation, 1980, "A Study on the Electrolysis of Sulfur Dioxide and Water for the Sulfur Cycle Hydrogen Production Process", AESD-TME-3043, July.

[3] Savannah River National Laboratory, 2005, "Characterization Testing of $\mathrm{H}_{2} \mathrm{O}-\mathrm{SO}_{2}$ Electrolyzer at Ambient Pressure", WSRC-TR-2005-00310, August.

[4] C. H. Fujimoto, M. A. Hickner, C. J. Cornelius and D. A. Loy, 2005, "Ionomeric Poly(phenylene) Prepared by Diels-Alder Polymerization: Synthesis and Physical Properties of a Novel Polyelectrolyte", Macromolecules, vol. 38, pp. 5010-5016. 